\title{
Effect of feeding Ksheerabala residue on growth and economics of production in Malabari kids
}

\author{
T. J. Roshma ${ }^{1}$, K. Ally ${ }^{2}$, Thirupathy Venkatachalapathy ${ }^{3}$, K. Shyama ${ }^{4}$ and K. George Sherin ${ }^{5}$ \\ Department of Animal Nutrition, College of Veterinary and Animal Sciences, Mannuthy, Thrissur, Kerala \\ Kerala Veterinary and Animal Sciences University, Pookode, Wayanad, India.
}

Citation: Roshma, T. J., Ally, K., Venkatachalapathy,T., Shyama, K. and George, S. K. 2021. Effect of feeding Ksheerabala residue on growth and economics of production in Malabari kids. J. Vet. Anim. Sci. 52(1): 60-64. DOI: https://doi.org/10.51966/jvas.2021.52.1.60-64

Received: 07.12.2020

Accepted: 17.12.2020

Published: 01.01.2021

\begin{abstract}
A feeding trial was done in 18 Malabari kids of 3 months of age (average body weight of $8.29 \pm 0.81 \mathrm{~kg}$ ) for a period of 90 days to assess the effect of dietary incorporation of Ksheerabala residue on growth performance and economics of production. Kids were randomly allotted into three dietary treatments $\left(T_{1}, T_{2}\right.$ and $\left.T_{3}\right)$ and were fed with kid starter containing Ksheearabala residue at 0,10 and 20 per cent, respectively. Kid starters were made isonitrogenous and isocaloric (24\% CP and 70\% TDN) and were fed as per ICAR standards (ICAR, 2013). Green grass (Hydrid Napier) was fed as source of roughage. Data on body weight gain, daily dry matter consumption, feed conversion efficiency and economics of production of the experimental kids were recorded. Average daily gain ( 82 and $73 \mathrm{~g}$ ) and feed conversion efficiency (4.49 and 4.80 ) were found to be similar in up $T_{1}$ and $T_{3}$ groups, however in $T_{2}$ group the gain $(54 \mathrm{~g})$ and $F C R(6.19)$ was significantly lower than $T_{1}$ and $T_{3}$. Feed cost per $\mathrm{kg}$ gain was found to be lowest (Rs. 80.85) for group $T_{3^{\prime}}$. It could be concluded that Ksheerabala residue can be incorporated in kid starter at 20 per cent level without affecting the growth performance of kids and it is more profitable.
\end{abstract}

Key words: Ksheerabala residue, kid starter, growth, economics

Increase in feed ingredient prices and the scarcity of grains are the most important constrains hindering animal production sector in India. Moreover, insufficient production of farm crops to meet the needs of both humans and their domestic animals leads to competition between man and animals for these feed ingredients. This has enforced animal nutrition researchers to

${ }^{*}$ Forms part of the MVSc thesis submitted by the first author to the Kerala Veterinary and Animal Sciences University, Pookode, Wayanad, Kerala.

1. Veterinary Surgeon, Animal Husbandry Department, Kerala

2. Professor and Head

3. Professor, University Goat and Sheep Farm, Mannuthy

4. Professor

5. Assistant Professor, Base Farm, Kolahalamedu Corresponding author Dr. Ally K, ally@kvasu.ac.in, Mob:9447476508

Copyright: (C) 2021 Roshma et al. This is an open access article distributed under the terms of the Creative Commons Attribution 4.0 International License (http://creativecommons.org/licenses/by/4.0/), which permits unrestricted use, distribution, and reproduction in any medium, provided the original author and source are credited.

60 Effect of feeding Ksheerabala residue on growth and... 
intensify their research into the feeding values of potentially useful and easily available nonconventional feed resources. Though various agro industrial by-products and crop residues are being used in animal feeds to reduce feed cost, the potential of by-products from ayurvedic pharmaceuticals has not been explored so far. Ksheerabala residue is a by-product obtained during the manufacturing of Ksheerabala oil which is prepared by combining Sida cordifolia, cow milk and gingelly oil. This residue is available in plenty, free of cost, but the level of inclusion and the effect of Ksheerabala residue on growth in kids are not yet studied. Hence the present study was done to evaluate the effect of dietary incorporation of Ksheerabala residue as a nonconventional feed in the ration of kids on their performance.

\section{Materials and methods}

Eighteen healthy kids of three months of age were selected from University Goat and Sheep farm, College of Veterinary and Animal Sciences, Mannuthy as the experimental animals and were housed individually in well aired, hygienic and dry shed with amenities for feeding and watering. The kids were allotted randomly in to three dietary treatments, $T_{1}$ (kid starter), $\mathrm{T}_{2}$ (kid starter containing 10 per cent ksheerabala residue) and $T_{3}$ (kid starter containing 20 per cent ksheerabala residue). All the rations were made isonitrogenous and isocaloric (24\% CP and $70 \%$ TDN).

Kid starter was offered in the forenoon and green grass (Hydrid Napier) was fed in the afternoon after weighing. Daily feed offered and left-over portion of the kid starter and green grass were recorded and moisture content was evaluated to calculate the dry matter intake. Body weights of animals were recorded at fortnightly intervals. Kids were fed as per ICAR standard (ICAR, 2013) and kept on their respective feeding regime for three months.

Kid starter, fodder and dung samples were evaluated for proximate principles (AOAC, 2012). The acid detergent fiber (ADF) was determined by the method suggested by Van Soest (1963) and neutral detergent fiber (NDF) by the method suggested by Van Soest and Whine (1967). Data collected on various parameters were statistically analysed using Analysis of Variance (Snedecor and Cochran, 1994). Cost of feeding per kg body weight gain was worked out. Proximate composition of Ksheerabala residue is depicted in Table 1. The ingredient and chemical composition of rations are depicted in Table 2.

\section{Results and discussion}

\section{Growth}

Data on the average body weight of kids belonging to groups $T_{1}, T_{2}$ and $T_{3}$ recorded at fortnight intervals (Table 2 ) revealed that the kids of all the three groups recorded similar pattern of gain, without any significant difference $(P>0.05)$. Kids of $T_{1}, T_{2}$ and $T_{3}$ had a cumulative weight gain of $6.39,4.23$ and $5.67 \mathrm{~kg}$ and an average daily body weight gain (ADG) of 82 , 54 and $73 \mathrm{~g} / \mathrm{d}$, respectively (Table 4). Statistical analysis of the data revealed that $\mathrm{T} 2$ group had significantly $(P<0.01)$ lower total gain and average daily gain compared to $T_{1}$ and $T_{3}$. The result in this study indicates that inclusion of Ksheerabala residue at 10 per cent level in kid starter ration reduced the growth rate of kids but at 20 per cent inclusion was comparable with that of control group.

Rani et al. (2016) observed similar daily gain in crossbred calves fed starter diets with dietary inclusion of Ksheerabala residue at 40 per cent level and control group. In contrary to the results, Obeidat and Gharaybeh (2011) observed higher weight gain in kids fed diet containing 10 per cent sesame hull compared to control diet with zero per cent sesame hull.

Table 1. Proximate composition of Ksheerabala residue

\begin{tabular}{|l|l|}
\hline \multicolumn{1}{|c|}{ Nutrients } & \multicolumn{1}{c|}{$\%$} \\
\hline Dry matter (DM) & 92.55 \\
\hline Crude protein (CP) & 29.52 \\
\hline Ether extract (EE) & 13.26 \\
\hline Crude fibre (CF) & 6.39 \\
\hline Total ash (TA) & 8.42 \\
\hline Nitrogen Free Extract (NFE) & 42.41 \\
\hline Acid insoluble ash (AIA) & 0.06 \\
\hline
\end{tabular}


Table 2. Ingredient and chemical composition of kid starters, with dietary incorporation of ksheerabala residue at different levels

\begin{tabular}{|l|c|c|c|}
\hline \multirow{2}{*}{ Ingredients, \% } & \multicolumn{3}{|c|}{ Percentage composition of kid starter } \\
\cline { 2 - 4 } & $T_{1}$ & $T_{2}$ & $T_{3}$ \\
\hline Maize & 35 & 29 & 23 \\
\hline Wheat bran & 25 & 26 & 28 \\
\hline Soya bean meal & 28 & 23 & 17 \\
\hline Dried fish & 9 & 9 & 9 \\
\hline Ksheerabala residue & 0 & 10 & 20 \\
\hline Salt & 1 & 1 & 1 \\
\hline Calcite & 2 & 2 & 2 \\
\hline Total & 100.00 & 100.00 & 100.00 \\
\hline Chemical composition & & & 91.93 \\
\hline Dry matter (DM) & 92.19 & 91.73 & 24.51 \\
\hline Crude protein (CP) & 23.74 & 23.99 & 6.04 \\
\hline Ether extract (EE) & 4.95 & 5.38 & 6.08 \\
\hline Crude fibre (CF) & 5.43 & 5.71 & 10.41 \\
\hline Total ash (TA) & 9.72 & 10.07 & 52.87 \\
\hline Nitrogen free extract (NFE) & 55.65 & 54.84 & 1.28 \\
\hline Acid insoluble ash (AIA) & 1.11 & 1.23 & 25.84 \\
\hline Neutral detergent fibre (NDF) & 22.34 & 22.83 & 9.48 \\
\hline Acid detergent fibre (ADF) & 6.61 & 7.81 & 1.18 \\
\hline Calcium & 1.03 & 1.12 & 0.86 \\
\hline Phosphorus & 0.65 & 0.70 & \\
\hline
\end{tabular}

Table 3. Fortnightly average body weight of experimental kids fed diets containing ksheerabala residue

\begin{tabular}{|c|c|c|c|}
\hline \multirow{2}{*}{ Fortnights } & \multicolumn{3}{|c|}{ Dietary treatments } \\
\cline { 2 - 4 } & $\mathrm{T}_{1}$ & $\mathrm{~T}_{2}$ & $\mathrm{~T}_{3}$ \\
\hline 0 & $8.27 \pm 0.58$ & $8.39 \pm 0.66$ & $8.23 \pm 1.25$ \\
\hline 1 & $9.31 \pm 0.64$ & $9.24 \pm 0.68$ & $9.01 \pm 1.44$ \\
\hline 2 & $10.37 \pm 0.59$ & $9.83 \pm 0.68$ & $10.05 \pm 1.59$ \\
\hline 3 & $11.00 \pm 0.53$ & $10.36 \pm 0.63$ & $11.19 \pm 1.75$ \\
\hline 4 & $12.42 \pm 0.53$ & $11.42 \pm 0.69$ & $12.26 \pm 1.83$ \\
\hline 5 & $13.34 \pm 0.5$ & $11.89 \pm 0.73$ & $13.29 \pm 1.72$ \\
\hline 6 & $14.66 \pm 0.63$ & $12.63 \pm 0.77$ & $13.91 \pm 1.72$ \\
\hline
\end{tabular}

Table 4. Growth rate, feed efficiency and cost of feeding per kg gain of kids fed with ksheerabala residue

\begin{tabular}{|l|c|c|c|}
\hline Parameters & $T_{1}$ & $T_{2}$ & $T_{3}$ \\
\hline Initial body weight $(\mathrm{kg})$ & $8.27 \pm 0.58$ & $8.39 \pm 0.66$ & $8.23 \pm 1.25$ \\
\hline Final body weight $(\mathrm{kg})$ & $14.66 \pm 0.63$ & $12.63 \pm 0.77$ & $13.91 \pm 1.72$ \\
\hline Total weight gain $(\mathrm{kg})$ & $6.39 \pm 0.13^{\mathrm{a}}$ & $4.23 \pm 0.23^{\mathrm{b}}$ & $5.67 \pm 0.54^{\mathrm{a}}$ \\
\hline Average daily gain (g) & $82 \pm 0.002^{\mathrm{a}}$ & $54 \pm 0.003^{\mathrm{b}}$ & $73 \pm 0.01^{\mathrm{a}}$ \\
\hline Total dry matter consumed (kg/calf) & $28.7 \pm 0.89$ & $26.17 \pm 1.58$ & $27.26 \pm 2.94$ \\
\hline Average daily dry matter consumed (kg/calf) & $0.37 \pm 0.01$ & $0.34 \pm 0.02$ & $0.35 \pm 0.04$ \\
\hline Feed efficiency & $4.49 \pm 0.13^{\mathrm{a}}$ & $6.19 \pm 0.21^{\mathrm{b}}$ & $4.8 \pm 0.26^{\mathrm{a}}$ \\
\hline Cost per kg gain (Rs.) & 91.97 & 115.92 & 80.85 \\
\hline
\end{tabular}




\section{Dry matter intake}

There was no significant difference in the average daily dry matter intake (DMI) and total DMI and the values were $0.37,0.34$ and $0.35 \mathrm{~kg}$ and $28.70,26.17$ and $27.26 \mathrm{~kg}$ respectively for $T_{1}, T_{2}$ and $T_{3}$ (Table 4 ). The result of present study is in agreement with Bambidis et al. (2005) who observed no significant difference in DMI of lambs which were fed with diet containing garlic bulb at zero, three and six per cent level. The results are in contrast with that of Rani et al (2016) and Sheethal et al (2016) who reported higher DMI in growing kids fed Ksheerabala residue at 40 per cent level inclusion.

\section{Feed conversion efficiency}

Feed conversion efficiency of experimental kids was 4.49, 6.19 and 4.80, respectively for $T_{1}, T_{2}$ and $T_{3}$ (Table 4 ) and statistical analysis of the data revealed that kids of $T_{3}$ had significantly lesser feed conversion efficiency $(P<0.01)$ compared to $T_{1}$ and $T_{3}$. From the results it can be inferred that inclusion of Ksheerabala at 10 per cent level in kid starter ration reduced the feed conversion efficiency but at 20 per cent level, feed conversion efficiency was similar to that of control group. In contrast to this findings, Jasmine et al. (2017) reported higher FCR (9.2) in kids fed starter diets containing rosemary residue.

\section{Economics of gain}

The cost of feed per kilogram body weight gain of kids maintained on dietary treatments $T_{1}$, $T_{2}$ and $T_{3}$ were Rs. 91.97, 115.92 and 80.85, respectively (Table 4 ). This result indicates that, kid starter containing 20 per cent Ksheerabala residue supported growth of kids similar to that of control ration and it is more economical.

\section{Conclusion}

Critical assessment of the results attained in the present study revealed that dietary incorporation of Ksheerabala residue at 10 per cent level in kid starter ration significantly reduced growth rate and feed conversion efficiency but at 20 per cent level, kids had similar growth rate as that of control group. Also, economics of production was lowest for kids maintained on kid starter containing 20 per cent Ksheerabala residue. From the overall results it can be concluded that inclusion of Ksheerabala residue at 20 per cent level in kid starter ration provided satisfactory growth rate and better profit.

\section{References}

AOAC. 2012. Official Methods of Analysis, (15 $5^{\text {th }}$ Ed.). Association of official analytical chemists. Washington, D.C, 587p.

Bampidis, V. A., Christodoulou, V., Paneri, F. P., Christaki, E.,Spais, A.B. and Chatzopoulu, P.S. 2005a. Effect of dried oregano leaves supplementation on performance and charcass characteristics of growing lambs. Anim. Feed Sci. Technol. 121: 275

BIS. 2012. Bureau of Indian Standards. Specification for compounded feeds for young stock: IS: 5560-(1970). Manak Bhavan, 9, Bhahaadur Shah Zafar Marg, New Delhi. 15p.

ICAR. 2013. Nutrient requirement of cattle and buffalo. Indian Council of Agriculture and Research, New Delhi, 30-34p.

Jasmine S M S., Shyama K., Gangadevi P., Ally $\mathrm{K}$ and Thirupathy Venkatachalapathy $R$. Effect of incorporation of spent rose mary leaves on serum biochemical parameters of Malabary kids. J. Vet. Anim. Sci. 2018. 49(7): 67-70

Obeidat, B.S. and Gharaybeh, F.F. 2011. Effect of feeding sesame hull on growth performance, nutrient digestibility, and carcass characteristics of Black goat kids. Asian-Aust. J. Anim. Sci. 24(2): 206

Rani, K. J., Ally K., Sheethal, C. R., Surej Joseph Banglavan, Gangadevi, P. and Shyama, K. 2016. Dietary incorporation of Ksheerabala residue and its effect on nutrient utilisation, growth performance and blood biochemical parameters in crossbred calves. Ind. J. Anim. Nutri. 33(4): 383-388. 
Sheethal C R, K.Jasmine Rani Surej Joseph Banglavan and Ally.K. Effect of incorporation of

Ksheerabala residue on dry matter intake and nutrient digestibility in crossbred calves. 2016. Int. J. Food Sci. Tech. 7(1): 7-11.

Snedecor, G.W. and Cochran, W.G. 1994. Statistical Methods. (8 $8^{\text {th }}$ Ed.). The Lowa State University press, Ames, IA. 314p.
Van Soest, P.J. 1963. Use of detergents in analysis of fibrous feeds. II. A rapid method for the determination of fibre and lignin. J. Assoc. Off. Analyt. Chem. 46: 829 .

Van Soest, P.J. and Whine, R.H. 1967. Use of detergents in the analysis of fibrous feeds. IV. The determination of plant cell wall constituents. J. Assoc. Off. Analyt. Chem. 50: 50. 